\title{
ZNAČAJ KOMUNIKACIJE U PREVENCIJI ANTIVAKCINALNIH AKTIVNOSTI
}

\author{
Darjan Franjić1 ${ }^{1}$ Ivana Franjić́ ${ }^{2}$, Jelena Ravlija ${ }^{3}$ \\ ${ }^{1}$ Klinika za onkologiju, Sveučilišna klinička bolnica Mostar, 88000 Mostar, BiH \\ ${ }^{2} J e d i n i c a$ intenzivnog liječenja, Sveučilišna klinička bolnica Mostar, 88000 Mostar, BiH \\ ${ }^{3}$ Fakultet zdravstvenih studija, Sveučilište u Mostaru, 88000 Mostar, BiH \\ Rad je primljen 2.10.2018. Rad je recenziran 1.11.2018. Rad je prihvaćen 9.11.2018
}

\section{SAŽETAK}

UVOD: Cijepljenje djece predstavlja učinkovit način za sprječavanje ozbiljnih bolesti u djetinjstvu, međutim, mnoga djeca ne primaju preporučena cjepiva. Komunikacija s roditeljima o cijepljenju u djetinjstvu je jedan od najvažnijih načina za rješavanje pitanja o cijepljenju.

CILJ: Cilj istraživanja bio je ispitati važnost komunikacije u prevenciji antivakcinalnih radnji te utvrditi koje izvore informacija o cijepljenju roditelji najčešće koriste. Dodatni cilj bio je procijeniti nedostatke u komunikaciji liječnika/sestre i roditelja kao moguće razloge odbijanja cijepljenja djece od strane roditelja.

METODE: Na prigodnom sustavnom uzorku od 60 roditelja primijenjen je anketni upitnik: Stavovi roditelja o cijepljenju u dječjoj dobi (Parent Attitudes about Childhood Vaccines (PACV). Upitnik je lingvistički validiran i odobren od strane autora. Ispitanici su bili roditelji djece dobi do 14. godine života koji su se u istraživačkom razdoblju zatekli u Dječjem dispanzeru Doma zdravlja Mostar.

REZULTATI: 67 \% ispitanika kao razlog cijepljenja navodi zaštitu djeteta od bolesti protiv kojih se cijepi, $13 \%$ misli da dijete treba cijepiti jer je cijepljenje zakonom obvezno, njih $23 \%$ ima stav da je veći rizik od bolesti nego od komplikacija cijepljenja. $83 \%$ ispitanika je redovito cijepilo djecu prema njihovoj odgovarajućoj dobi, dok njih $17 \%$ nije. $67 \%$ ispitanika tvrdi da im liječnik ili sestra objasne postupak cijepljenja, njih 31 \% tvrdi da im se djelomično objasni postupak cijepljenja, dok $2 \%$ ispitanika tvrdi da im se ne objasni postupak cijepljenja.

ZAKLJUČAK: Najčešćim izvorom informacija o cijepljenju roditelji navode zdravstvene djelatnike, ali i internet, prijatelje. Zdravstveno osoblje treba biti izvor pouzdanih informacija o koristi, ali i mogućim nuspojavama cijepljenja. Ključne riječi: cijepljenje, komunikacija, prevencija, informacija, antivakcinalni pokret

Osoba za razmjenu informacija:

mr. Darjan Franjić;

email: darjanfranjic@gmail.com

\section{UVOD}

Cijepljenje djece predstavlja učinkovit način za sprječavanje ozbiljnih bolesti u djetinjstvu, međutim, mnoga djeca ne primaju preporučena cjepiva. Postoje razni razlozi za to: neki roditelji nemaju pristup zbog loše kvalitete zdravstvenih usluga, dugih udaljenosti ili nedostatka novca. Drugi roditelji, pak, ne vjeruju cjepivima ili zdravstvenim djelatnicima ili možda ne vide potrebu za cijepljenjem zbog nedostatka informacija. Jedan od razloga zbog kojeg roditelji odbijaju cijepljenje mogu biti dezinformacije o tome kako se provodi cijepljenje. Komunikacija s roditeljima o cijepljenju u djetinjstvu je jedan od najvažnijih načina za rješavanje pitanja o cijepljenju (1). Budući da je stav roditelja prema cijepljenju najznačajniji prediktor donošenja odluke o cijepljenju, tome treba pridati veliku važnost (2). Roditelji koji ne cijepe djecu razlikuju se od onih koji cijepe po nizu karakteristika, pa je tako pronađeno da oni koji odbijaju cijepiti djecu smatraju cjepiva neučinkovitima, a bolesti zbog kojih 
se djeca cijepe bezopasnima ili manje opasnima od posljedica cijepljenja (3).

Aktivnosti protiv cijepljenja potječu još od 18 . stoljeća kada propovjednik Reverend Edmund Massey 1772. godine naziva cijepljenje „dijabetičkom operacijom“ u svojoj propovijedi „Opasne i grješne prakse cijepljenja, (4). Antivakcinalni pokret je posljednjih godina snažno obnovljen objavom znanstvenog rada u Lancet-u od strane britanskog liječnika Andrewa Wakefilda koji je potvrdio povezanost cjepiva protiv ospica, zaušnjaka i rubeole sa pojavom autizma kod djece (5). Nekoliko studija koje su poslije objavljene su opovrgnule povezanost ove vrste cjepiva sa autizmom (6-9).Ranija istraživanja navode da se među glavne prediktore antivakcinalnih aktivnosti ubrajaju: nedostatak znanja, pogrešna percepcija te nepovjerenje u cjepiva koje je najčešće u kombinaciji s niskom percepcijom rizika od antivakcinalnih radnji (10).

Povjerenje u cijepljenje je jedan od najvažnijih preduvjeta za razumijevanje važnosti prihvaćanja cijepljenja (11-17). Razina povjerenja roditelja u vla$\mathrm{du}$, javno-zdravstveni sustav i u usluge javno-zdravstvenog sustava je često povezana sa njihovom odlukom o prihvaćanju ili odbijanju preporučenog cjepiva za njihovu djecu. Mnoge studije su pokazale da je povjerenje roditelja u usluge javno-zdravstvenog sustava na visokoj razini (18). Istraženo je da su pitanja o ozbiljnosti bolesti te o učinkovitosti i sigurnosti cjepiva najčešća kada je riječ o roditeljskoj percepciji u odnosu na osjetljivost njihovog djeteta na cijepljenjem preventivne bolesti $(19,20)$. Nadalje, roditeljski stavovi o cijepljenju i njihovo pouzdanje u cijepljenje su pod snažnim utjecajem percepcije društvenog kriterija. Društveni kriteriji mogu utjecati i na spoznajne heuristike koje ljudi koriste kada donose odluke koje su u odnosu sa zdravstvom i medicinom, uključujući i odluke koje se odnose na imunizaciju (21). Spoznajne heuristike predstavljaju prečice u odlučivanju koje se koriste ili za ubrzavanje procesa odlučivanja ili donošenja konačne odluke.

Mediji su odigrali važnu ulogu u stvaranju negativnog stava prema cijepljenju, čak i usprkos snažnim dokazima o sigurnosti i učinkovitosti cijepljenja. $\mathrm{Uz}$ tradicionalne medije, poruke koje promoviraju antivakcinalne aktivnosti najčešće se prenose internetom (22). Dosadašnja istraživanja pokazala su da roditelji djece koja se nisu cijepila po zahtjevu škole o vakcinaciji imaju drugačije stavove o cijepljenju u odnosu na roditelje djece koja su se redovito odazivala zahtjevu škole za cijepljenje (23).Roditeljsko vjerovanje u obaveznost vakcinacije prije upisa u školu njihove djece je povezano sa vjerovanjem $\mathrm{u}$ sigurnost i korisnost imunizacije (24). Čini se da mnogi školski djelatnici nisu svjesni ozbiljnosti nekih bolesti koje se mogu spriječiti cijepljenjem kao i činjenice da su djeca koja nisu cijepljena vrlo osjetljiva na bolesti. Školsko osoblje, koje je bez formalne obuke o zdravstvenoj skrbi, a koje savjetuje roditelje o pitanjima cijepljenja, mogu doprinijeti dezinformaciji roditelja (25).

Iako komunikacija predstavlja ključan faktor u programu cijepljenja, do danas nije postignut opsežan pristup organiziranja komunikacijskih intervencija koje se mogu pružiti roditeljima i zajednici radi boljeg razumijevanja cijepljenja i jednostavnijeg donošenja odluke u vezi cijepljenja njihovog djeteta (26). Na osnovi informacija roditelj mora shvatiti važnost cijepljenja, kao i važnost pridržavanja vremenskog slijeda u kalendaru cijepljenja kako bi se postigla adekvatna zaštita djeteta (27). Aktivisti antivakcinalnog pokreta prenose informacije o štetnosti cijepljenja koje nisu temeljene na dokazima. Takve informacije, pak, izazivaju strah od cijepljenja i potiču antivakcinalne radnje kod čitave generacije roditelja. Dosadašnja istraživanja pokazuju da najučinkovitije metode koje javnozdravstveni sustavi trebaju koristiti za borbu protiv antivakcinalnih aktivnosti su statistika, istraživanja te komunikacija, to jest širenje informacija o cijepljenju koje su temeljene na znanstvenim dokazima (28).

Cilj istraživanja bio je ispitati važnost komunikacije u prevenciji antivakcinalnih radnji te utvrditi koje izvore informacija o cijepljenju roditelji najčešće koriste. Dodatni cilj bio je procijeniti nedostatke u komunikaciji liječnika/sestre i roditelja kao moguće razloge odbijanja cijepljenja djece od strane roditelja.

\section{ISPITANICI I METODE}

$\mathrm{Na}$ prigodnom sustavnom uzorku od 60 roditelja primijenjen je anketni upitnik. Ispitanici su bili 
roditelji djece dobi do 14 . godine života koji su se u istraživačkom razdoblju zatekli u Dječjem dispanzeru, Doma zdravlja Mostar. Istraživanje je obavljeno u razdoblju od veljače do travnja 2018. godine. Prije same provedbe istraživanja dobivena je pisana suglasnost Povjerenstva za etička istraživanja Sveučilišne kliničke bolnice Mostar dana 27.1.2018. Prije provođenja istraživanja svi ispitanici su potpisali obavijesni pristanak za sudjelovanje u njemu. Dragovoljno su pristali sudjelovati što su potvrdili svojim potpisom. Istraživanje je provedeno u skladu s etičkim načelima i ljudskim pravima u istraživanju.

Anonimnim anketnim upitnikom prikupljeni su sociodemografski podatci korištenjem upitnika za ispitivanje stavova o cijepljenju u dječjoj dobi: Parent Attitudes about Childhood Vaccines Survey (PACV) (29). Navedeni anketni upitnik PACV lingvistički je validiran i odobren od strane autora (Douglas Opel). Upitnik oblikovan za potrebe ovog istraživanja sadržavao je sociodemografske podatke (dob, spol, mjesto stanovanja, bračni status, razinu obrazovanja, tjedan trudnoće, broj djece) te pitanja koja sadržavaju informacije o dosadašnjim izvorima o cijepljenju, potrebom edukacije i izvorima informacija o cijepljenju u dječjoj dobi.

Upitnik PACV, kojim se ispitivala zabrinutost i neodlučnost u svezi s cijepljenjem, sastoji se od 20 čestica. Upitnik sadrži 17 pitanja zatvorenog tipa, tri su pitanja sodgovorima da i ne, tri su pitanja otvorenog tipa, to jest pitanja u kojima nisu ponuđeni odgovori. Ukupna skala stavova računa se od 0 do 100 bodova pri čemu 25 bodova i više označava neodlučnost. Iako je autor PACV upitnika postavio granicu 50 i više bodova koja označavaju neodlučnost, ostala istraživanja koja su provedena PACV upitnikom smanjili su bodovni prag na 25 bodova i više jer su smatrali kako je grubo podijeljen prag na 50 i više te su htjeli istaknuti što preciznije prepoznavanje neodlučnih roditelja te je iz istih razloga u ovom istraživanju također korišten niži bodovni prag. Koeficijent pouzdanosti cijele skale stavova, Cronbach Alpha, iznosi 0,835.

Stav medicinskih sestara prema cijepljenju ispitan je primjenom metodologije fokus grupe. Fokus grupa se sastoji od 8 medicinskih sestara sa Klinike za dječje bolesti koje ispunjavaju određene uvjete: da su diplomirane medicinske sestre sa minimalno 5 godina radnog iskustva i da su majke.

\section{Statističke metode obrade podataka}

Kategorijski su podatci predstavljeni apsolutnim i relativnim frekvencijama. Prikupljeni podaci, nakon njihove logičke obrade, su uneseni u bazu podataka MS Excel 2013. Za statističku analizu korišten je program MedCalc Statistical Software version 14.12.0 (MedCalc Software bvba, Ostend, Belgium; http://www.medcal.org;2014). Granica statističke značajnosti postavljena je na 0,05 . Nominalne i ordinalne varijable uspoređene su hi-kvadrat testom, a pri manjku očekivane frekvencije korišten je Fischerov egzaktni test.

\section{REZULTATI:}

Od 60 ispitanika koliko ih je uključeno u istraživanje, najveći broj ispitanika ima samo srednjoškolsko obrazovanje te visoku stručnu spremu $\left(\chi^{2}=6,118\right.$; $\mathrm{df}=3 ; \mathrm{p}=0,106)$ (Tablica 1$)$.

Tablica 1. Prikaz ispitanika prema razini obrazovanja

\begin{tabular}{|c|c|c|}
\hline Razina obrazovanja & \% ispitanika & \multirow{2}{*}{$\mathrm{p}^{*}$} \\
\hline Osnovno obrazovanje & $3 \%$ & \multirow{2}{*}{0} \\
\cline { 1 - 2 } Srednja škola & $38 \%$ & \\
\hline Viša stručna sprema & $26 \%$ & \\
\hline Visoka stručna sprema & $33 \%$ & \\
\hline
\end{tabular}

${ }^{\star}$ Hi kvadrat - test

Sljedeći parametar koji smo ispitivali je glavni razlog odbijanja cijepljenja djece. Najveći broj ispitanika glavnim razlogom odbijanja cijepljenja smatra strah od komplikacija, 8 ispitanika navode da je razlog taj što roditelji misle da je bolje da dijete preboli bolest, a 2 ispitanika navodi zato jer je to u "tren$\mathrm{du}^{\prime \prime}\left(\chi^{2}=14,02 ; \mathrm{df}=3 ; \mathrm{p}=0,002\right)$.

Nadalje, analizirali smo koje bi informacije o cijepljenju i cjepivima ispitanici trebali ili htjeli čuti od zdravstvenih djelatnika. Najveći broj ispitanika misli da bi trebali od zdravstvenih djelatnika čuti koje cjepivo, protiv koje bolesti dijete prima, njih 10 tko je proizvođač cjepiva, njih 12 koje su nuspojave, a 4 ispitanika navode da bi od zdravstvenih djelatnika 
htjeli čuti sastav cjepiva koje dijete treba primiti $\left(\chi^{2}=7,871 ; \mathrm{df}=3 ; \mathrm{p}=0,048\right)$.

Ispitali smo koji je najčěšći izvor informacija o cijepljenju kod ispitanika koji su uključeni u istraživanje. Od 60 ispitanika, njih $50 \%$ najčešćim izvorom smatraju zdravstvene djelatnike, njih $10 \%$ članove obitelji, $47 \%$ ispitanika navodi medije, dok je $3 \%$ ispitanika navelo prijatelje, a nitko od ispitanika izvorom ne smatra nevladine organizacije $\left(\chi^{2}=11,578\right.$; $\mathrm{df}=3 ; \mathrm{p}=0,008)$.

Sljedeći parametar koji smo analizirali je stav ispitanika o informiranju od strane liječnika /sestre. Najveći broj ispitanika tvrdi da im liječnik/sestra objasne svaki put koje cjepivo i protiv kojih bolesti dijete prima isto, a najmanji broj ispitanika tvrdi da im liječnik/sestra nikad ne objasne postupak i razloge cijepljenja $\left(\chi^{2}=7,196 ; \mathrm{df}=2 ; \mathrm{p}=0,027\right)$ (Tablica 2$)$.

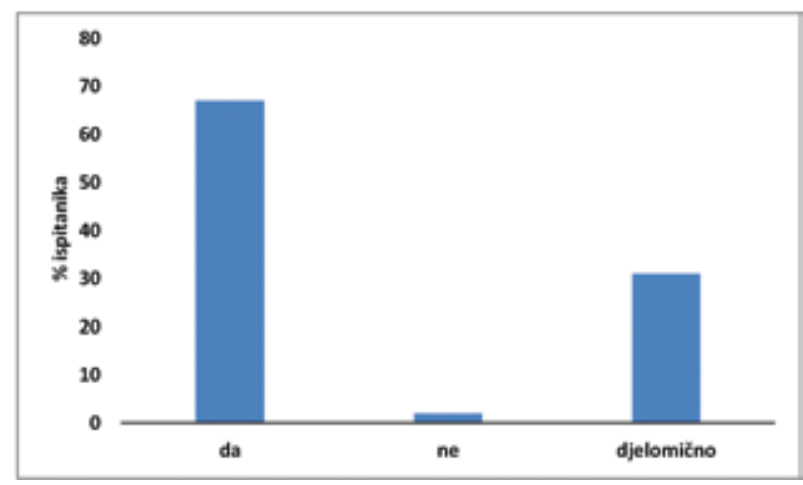

Slika 1. Stav roditelja o korisnosti cijepljenja za prevenciju određenih bolesti

Tablica 2. Stav ispitanika o informiranju o cijepljenju od strane liječnika/sestre

\begin{tabular}{|c|c|c|}
\hline Stav ispitanika & \% ispitanika & \multirow{2}{*}{$\mathrm{p}^{*}$} \\
\hline Da, svaki put & $60 \%$ & \multirow{2}{*}{0,027} \\
\hline Ponekad & $33 \%$ & \\
\hline Nikad & $7 \%$ & \\
\hline
\end{tabular}

${ }^{\star}$ Hi kvadrat test

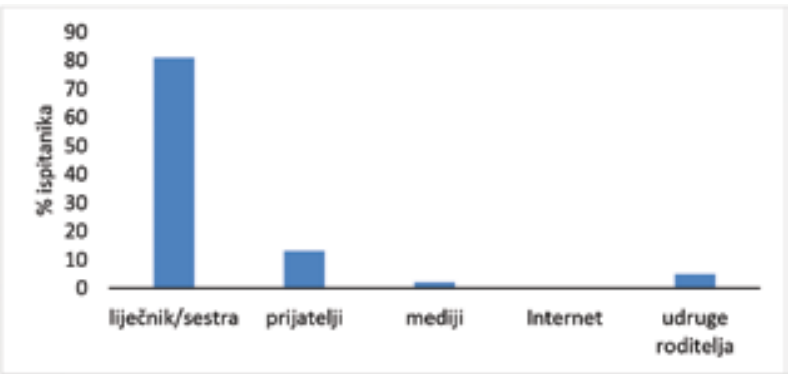

Slika 2. Stav ispitanika o razini povjerenja po pitanju cijepljenja

Ispitali smo stav roditelja o korisnosti cijepljenja za prevenciju određenih bolesti. Rezultati su pokazali da najveći broj ispitanika smatra cijepljenje korisnim za prevenciju određenih bolesti, dok mali broj ispitanika smatra da cijepljenje nije korisno za prevenciju određenih bolesti $\left(\chi^{2}=10,75 ; \mathrm{df}=2\right.$; $\mathrm{p}=0,004)$ (Slika 1).

S obzirom da je u Bosni i Hercegovini cijepljenje zakonska obaveza, smatrali smo da bi bolju sliku namjere sudionika o cijepljenju dobili postavljajući pitanje o hipotetskoj odluci kada zakonska regulativa ne bi postojala. Rezultati ispitivanja ovog parametra pokazuju da $47 \%$ ispitanika navodi da bi cijepili dijete i onda kada cijepljenje ne bi bilo zakonom obavezno, njih $7 \%$ navodi da ne bi cijepili dijete kad cijepljenje ne bi bilo zakonom obavezno dok njih $46 \%$ nije sigurno da li bi cijepili svoje dijete kada cijepljenje ne bi bilo zakonom obavezno. Dakle, gotovo jednak je postotak roditelja koji bi sigurno cijepili dijete s postotkom roditelja koji nisu sigurni da bi cijepili dijete u slučaju da cijepljenje nije zakonski obavezno $\left(\chi^{2}=6,667 ; \mathrm{df}=2 ; \mathrm{p}=0,035\right)$.

Rezultati pokazuju da osobe u koju roditelji najviše imaju povjerenja po pitanju cijepljenja su liječnik i/ili sestra. Najmanje povjerenja po pitanju cijepljenja ispitanici imaju u medije i Internet $\left(\chi^{2}=22,339\right.$; $\mathrm{df}=3 ; \mathrm{p}<0,001)($ Slika 2$)$.

Za ovo istraživanje je primijenjena i fokus grupa od 8 medicinskih sestara $s$ Klinike za dječje bolesti, koje su imale više od 5 godina radnog iskustva, prvostupnice sestrinstva, te koje su u statusu majke. Tijekom razgovora na unaprijed planirana pitanja o stavu prema cijepljenju, sestre su diskutirale vrlo otvoreno. Pitanjem o njihovom stavu, a koji se odnosi na korisnost cjepiva, otvorena je diskusija. Prisutne medicinske sestre imale su jedinstven stav, koji glasi da je cjepivo korisno i nužno. Nazočna sestra navodi kako je prvo svoje dvoje djece cijepila bez imalo razmišljanja i straha, a već za treće je imala strah. Zaključuje daje isti prouzrokovan medijskim kampanjama protiv cjepiva koji ne navode nikakve dobre strane, samo loše.

Na pitanje plaše li se komplikacija cjepiva, imale su također jedinstven stav. Smatraju da je korist veća 
od rizika. Također, jedna sestra navodi kako svaki lijek može imati nuspojave, pa tako i cjepivo. Zatim, mišljenje jedne sestre da roditelji koji imaju djecu, primljenu s neurološkim problemima, često bezrazložno stavljaju kao razlog cjepivo, zbog toga što je to možda "njihov obrambeni i utješni mehanizam". Potrebno je ipak skrenuti pažnju i staviti veći naglasak na kvalitetu cjepiva, kazala je jedna medicinska sestra. Sestra naglašava da je potrebna odgovornost i veliki oprez kako od strane proizvođača, tako i od zdravstvenog osoblja. Razlog veće brige zdravstvenih djelatnika je u tome, što od njih roditelji traže konkretan odgovor, hoće li cijepiti dijete ili ne. Zbog toga medicinske sestre izjavljuju kako su u nezahvalnoj situaciji svakim danom, pa čak i na ulici.

Po mišljenju medicinskih sestara, najvažnije je roditeljima reći da je cijepljenje obavezno te da time činimo prevenciju, odnosno sprečavamo pojavu infektivnih bolesti koje su nekada bile jako opasne i naravno smrtonosne. Pitanje je jedne sestre: „Zašto poslati svoje dijete u vrtić sa nekim djetetom koje se nije cijepilo"? Dakle, to smatra neispravnim i protivi se tome.

Glavni razlog zašto medicinske sestre često izbjegavaju razgovor sa roditeljima, prema mišljenju ispitanika, jest taj što smatraju da nemaju ovlasti reći roditeljima da cijepe ili ne cijepe svoje dijete. Ipak, naglašavaju da roditeljima treba reći dobre i loše strane, te da roditelji o cijepljenju trebaju biti informirani u savjetovalištu Doma zdravlja, a ne u kliničkoj ustanovi, što je česta praksa. Medicinske sestre priznaju svoju povremenu pasivnost u određenim situacijama, a pravdaju je zbog poteškoće donošenja odluka u ime roditelja i zbog umanjenih kompetencija. U potpunosti se slažu da cijepljenje svakako mora ostati zakonom obavezno.

\section{RASPRAVA}

Budući da su u našem uzorku gotovo najviše zastupljeni visokoobrazovani roditelji, ovako loše znanje na prvu ruku zaista djeluje iznenađujuće. Istraživanje koje su proveli Stefanoff i suradnici pokazalo je da visokoobrazovane majke imaju negativne stavove prema cijepljenju, dok su dva istraživanja u Sjedinjenim Američkim Državama (SAD) dobila da visokoobrazovani roditelji imaju manje briga o sigurnosti cjepiva, te da imaju veći stupanj procijepljenosti djece (30). Rezultati našeg istraživanja pokazuju da roditelji imaju relativno pozitivan stav prema cijepljenju. Ovakvi rezultati su u skladu $s$ rezultatima istraživanja provedenim u drugim europskim zemljama koji su pokazali da se roditelji uglavnom ne protive cijepljenju te imaju pozitivne stavove o njegovoj primjeni, kao što su rezultati Coniglia i Stefanoffa $(30,31)$. Naši rezultati su pokazali da najveći broj ispitanika smatra cijepljenje korisnim za prevenciju određenih bolesti. Ovi podaci se podudaraju sa podacima istraživanja koje su proveli Rogersi suradnici 2014. godine. Oni pokazuju da $94 \%$ roditelja smatra cijepljenje korisnim za prevenciju određenih bolesti (32). Na pitanje kod koga se roditelji najčešće informiraju o cjepivima naši rezultati pokazuju da osobe u koju roditelji najviše imaju povjerenja po pitanju cijepljenja su liječnik/sestra. Zanimljivo je kako izvor koji se uopće ne koristi pri informiranju o cijepljenju predstavljaju ginekolozi, koji imaju snažan utjecaj na ženu tijekom trudnoće i pripreme za porod. Link-Gelles i suradnici 2012. godine istražili su stavove ginekologa i porodničara i pružanje informacija o cijepljenju svojim pacijenticama tijekom prenatalne skrbi. Iako većina ginekologa i porodničara smatra cijepljenje djece važnim, puno manji broj smatra da može utjecati na odluke majki o cijepljenju (33).

Rezultati našeg istraživanja pokazuju da bi gotovo polovina ispitanika cijepilo svoje dijete i kada to ne bi bilo obavezno zakonom. Stoga je zabrinjavajuća i činjenica da inicijative koje promiču slobodu izbora pri odluci o cijepljenju traže ukidanje zakonske regulative kakva u Bosni i Hercegovini trenutno postoji, a naši rezultati pokazuju da i među roditeljima koji trenutno poštuju zakone postoje oni koji bi, bez zakonske regulative, odlučili drugačije. Roditelji koji su skloni cijepljenu značajno se razlikuju od roditelja koji nisu skloni cijepljenju djece u nizu varijabli: stavovima o cijepljenju, znanju o cjepivima i njihovim nuspojavama. Kao što je spomenuto ranije, roditelji podcjenjuju rizik od necijepljena, odnosno podcjenjuju zaštitnu ulogu cjepiva od bolesti. Upravo vjerovanje u taj zaštitni faktor cjepiva pokazao 
se ključnim u formiranju pozitivnih stavova prema cijepljenju, kao što je pokazala studija Ticknera i suradnika (34). Da su stavovi važan čimbenik kod pristanka na cijepljenje pokazalo je Cooperovo istraživanje koje je provedeno 2008. godine u kojem su roditelji koji su pristali na cijepljenje svojih kćeri protiv HPV-a (od eng. human papiloma virus) imali značajno bolje stavove prema cijepljenju, nego roditelji koji nisu pristali (35). Naši rezultati pokazuju da najveći broj ispitanika kao razlog cijepljenja navodi zaštitu djeteta od bolesti protiv kojih se cijepi. Rezultati koje su dobili Tickner i suradnici također pokazuju da najveći broj ispitanika kao razlog cijepljenja navodi zaštitu djeteta od bolesti protiv koje se cijepi. Naše istraživanje je pokazalo da najveći broj ispitanika smatra zdravstvene djelatnike kao najvažniji izvor informacija o cijepljenju. Ovi rezultati se podudaraju sa rezultatima koje su dobili Ashbaugh i suradnici u svom istraživanju koje je provedeno 2013. godine (36). U njihovim rezultatima je također vidljivo da je najveći broj ispitanika za izvor informacija o cjepivu smatrao zdravstvene djelatnike.

Analizom rezultata fokus grupe našeg istraživanja došli smo do zaključka da se oni podudaraju sa istraživanjem koje su proveli Willis i suradnici 2013. godine. $U$ njihovom istraživanju medicinske sestre su također imale pozitivan stav o cijepljenju (37). Salmon i suradnici navode da roditelji koji su prihvatili svaki školski zahtjev za vakcinaciju njihove djece vjeruju da su njihova djeca imala koristi od vakcinacije (38). Njihovi rezultati također pokazuju da ovi roditelji imaju više pouzdanja u sigurnost $\mathrm{i}$ učinkovitost vakcinacije, dok rezultati koje su dobili Kennedy i suradnici pokazuju da roditeljsko vjerovanje $\mathrm{u}$ obaveznost vakcinacije prije upisa $\mathrm{u}$ školu njihove djece je povezano sa vjerovanjem $u$ sigurnost i korisnost imunizacije (39). Također, $\mathrm{u}$ istraživanju koje je proveo Salmon sa suradnicima o stavovima medicinskog osoblja o antivakcinalnim aktivnostima analiziran je utjecaj školskog osoblja na stavove i dezinformaciju roditelja o cijepljenju. Oni navode da bi medicinske sestre ili dobro obučeno medicinsko osoblje trebali biti osnovni kontakti za roditelje koji imaju pitanja o vakcinalnim aktivnostima, a to također pokazuju i naši rezultati
(40). Provedena su brojna istraživanja o tome tko daje informacije vezane uz cijepljenje djece, na koji način su te informacije dane, kojem izvoru informacija roditelji vjeruju i kada roditelji uopće traže informaciju (41-43). Naši rezultati pokazuju da su zdravstveni djelatnici i mediji najčešći izvor informacija o cijepljenju. Fairbrother i suradnici navode da roditelji traže informacije i odgovore iz različitih izvora kao što su djelatnici javnog zdravstva, pedijatri i drugi zdravstveni radnici koji rade s djecom, članovi obitelji, prijatelji, mediji (tiskovni, TV), blogovi, različiti internetski izvori, interesne skupine i udruge (43). Pristup medicinskim informacijama na internetu mnogo je promijenio odnos pacijenta i doktora. Pacijent na osnovu medicinskih informacija pronađenih na internetu smjelije sam donosi vrlo bitne odluke za zdravlje svoga djeteta pritom ne provjeravajući vrijednost tih informacija, za razliku od vremena kada su liječnici bili jedini izvor medicinskih informacija. Forknerovi rezultati pokazuju da dostupnost medicinskih informacija na internetu uvelike utječe na donošenje odluke roditelja o cijepljenju njihovog djeteta (44).

Kada je riječ o cijepljenju, na internetu je vrlo lako naći pogrešne informacije. Analiza rezultata koje su dobili Keeleane i suradnici u studiji o You tube prikazima o cijepljenju pokazuje da njih $32 \%$ negativno predstavlja cijepljenje. Prema njima, You tube videa koji cijepljenje prikazuju u negativnom kontekstu su bolje rangirani i imaju više pregleda $\mathrm{u}$ usporedbi s onim You tube videima koji promoviraju cijepljenje (45). Sličnu studiju o prenošenju informacija o imunizaciji preko interneta uradili su Seeman i suradnici u Kanadi 2010. godine. Analiza njihovih rezultata pokazala je da $60 \%$ informacija koje se prenose preko interneta (Facebook, Twitter, You tube, Digg) promoviraju antivakcinalne aktivnosti (46). Kata i suradnici u svojoj studiji o antivakcinalnim aktivnostima pokazuju da autori online antivakcinalnog pokreta koriste razne taktike za širenje poruka protiv cijepljenja, kao što su: pogrešno tumačenje znanstvenih činjenica, napadanje onih koji imaju suprotno mišljenje od njih, tvrdnje da nisu dio antivakcinalnih aktivnosti nego da se 
zalažu za sigurno cijepljenje te tvrde da su cjepiva otrovna ili neprirodna (47).

Analiza naših rezultata koji su dobiveni ispitivanjem fokus grupe pokazuje da su ispitanicima najveći strah od cijepljenja izazvale medijske kampanje jer ističu samo loše strane cijepljenja, što se podudara s rezultatima Kate i suradnika. Rezultati pokazuju da roditelji najviše povjerenja za dobivanje informacija o cijepljenju imaju u liječnika i medicinsku sestru, a najmanje povjerenja za dobivanje informacija o cijepljenju imaju u internet. Ovakvi rezultati pokazuju da roditelji još uvijek imaju svijest da mnoštvo online informacija o cijepljenju nisu temeljene na znanstvenim dokazima, te da nisu relevantne za donošenje konačne odluke o cijepljenju njihovog djeteta.

\section{ZAKLJUČCI}

Nepovjerenje u cijepljenje i antivakcinalni pokreti postaju dio društva. Potrebne su nove javnozdravstvene mjere u smislu edukacije zdravstvenog osoblja i šire javnosti po pitanju prevencije dječjih zaraznih bolesti. Iz rezultata istraživanja došli smo do zaključka da najčešćim izvorom informacija o cijepljenju roditelji navode zdravstvene djelatnike, ali i internet, prijatelje. Zdravstveno osoblje treba biti izvor pouzdanih informacija o koristi, ali i mogućim nuspojavama cijepljenja. Liječnici, kao i svi zdravstveni djelatnici, se moraju educirati o različitim modelima komunikacije s roditeljima u svrhu prenošenja pravovaljanih i znanstveno dokazanih informacija o cijepljenju.

\section{REFERENCE:}

1. Ames HM, Glenton C, Lewin S. Parents' and informal caregivers' views and experiences of communication about routine childhood vaccination: a synthesis of qualitative evidence. Cochrane Database Syst Rev. 2017 Feb 7;(2): CD011787

2. Tickner S, Leman PJ, Woodcock A. The immunisation beliefs and intentions measure (IBIM): predicting parents' intentions to immunise preschool children. Vaccine. 2010;(28); 3350-3362

3. Brown KF, Kroll JS, Hudsonc MJ, Ramsayd M, Greene J, Longa SJ et al. Factors underlying pa- rental decisions about combination childhood vaccinations including MMR: A systematic review. Vaccine. 2010;(28); 4235-4248

4. Hussain A, Ali S, Ahmed M, Hussain S. The anti-vaccination movement: a regression in modern medicine.cureus. 2018 Jul 3;10(7):e2919

5. Wakefield AJ, Murch SH, Anthony A. Ileal-lymphoid-nodular hyperplasia, non-specific colitis, and pervasive developmental disorder in children. Lancet. 1998;351:637-641.

6. Taylor B, Miller E, Farrington CP. Autism and measles, mumps, and rubella vaccine: no epidemiological evidence for a causal association. Lancet. 1999;353:2026-2029.

7. Fombonne E, Chakrabarti S. No evidence for a new variant of measles-mumps-rubella-induced autism. Pediatrics. 2001;108:0.

8. Farrington CP, Miller E, Taylor B.MMR and autism: further evidence against a causal association. Vaccine. 2001;19:3632-3635.

9. DeStefano F, Thompson WW.MMR vaccine and autism: an update of the scientific evidence. Expert Rev Vaccines. 2004;3:19-22.

10.Herzog R, Álvarez-Pasquin MJ, Díaz C, Del Barrio JL, Estrada JM, Gil Á. Are healthcare workers' intentions to vaccinate related to their knowledge, beliefs and attitudes? A systematic review. BMC Public Health. 2013 Feb;13;154

11. Roush SW, Murphy TV. Vaccine- preventable disease table working group. Historical comparisons of morbidity and mortality for vaccine-preventable diseases in the United States. JAMA. 2007;298:2155-63

12. Falagas ME, Zarkadoulia E. Factors associated with suboptimal compliance to vaccinations in children in developed countries: a systematic review. Curr Med Res Opin. 2008;24:1719-41

13. Brown KF, Kroll JS, Hudson MJ, Ramsay M, Green J, Long SJ et al. Factors underlying parental decisions about combination childhood vaccinations including MMR: a systematic review. Vaccine. 2010;28:4235-48

14. Yaqub O, Castle-Clarke S, Sevdalis N, Chataway J. Attitudes to vaccination: a critical review. Soc Sci Med. 2014;112:1-11 
15. Larson HJ, Jarrett C, Eckersberger E, Smith DM, Paterson P. Understanding vaccine hesitancy around vaccines and vaccination from a global perspective: a systematic review of published literature, 2007-2012. Vaccine. 2014;32:2150-9

16. Sturm LA, Mays RM, Zimet GD. Parental beliefs and decision making about child and adolescent immunization: from polio to sexually transmitted infections. J Dev Behav Pediatr. 2005;26:441-52

17. Mills E, Jadad AR, Ross C, Wilson K. Systematic review of qualitative studies exploring parental beliefs and attitudes toward childhood vaccination identifies common barriers to vaccination. J Clin Epidemiol. 2005;58:1081-8

18. Roberts KA, Dixon-Woods M, Fitzpatrick R, Abrams KR, Jones DR. Factors affecting uptake of childhood immunisation: a Bayesian synthesis of qualitative and quantitative evidence. Lancet. 2002;360:1596-9

19. Kennedy A, Lavail K, Nowak G, Basket M, Landry S. Confidence about vaccines in the United States: understanding parents' perceptions. Health Aff (Millwood) 2011;30:1151-9

20. Gargano LM, Weiss P, Underwood NL, Seib K, Sales JM, Vogt TM et al. School-located vaccination clinics for adolescents: correlates of acceptance among parents. J Community Health. 2015;40:660-9

21. Rosenstock I. Historical origins of the Health Belief Model. Health Educ Behav. 1974;2:328-35

22. Dubé E, Laberge C, Guay M, Bramadat P, Roy R, Bettinger JA. Vaccine hesitancy. Hum Vaccin Immunother. 2013; 9(8):1763-73

23. Salmon DA, Moulton LH, Omer SB, deHart MP, Stokely S, Halsey NA. Factors associated with refusal of childhood vaccines among parents of school-aged children: a case-control study. Arch Pediatr Adolesc Med. 2005;159:470-6

24. Kennedy AM, Brown CJ, Gust DA. Vaccine beliefs of parents who oppose compulsory vaccination. Public Health Rep. 2005;120:252-8

25. Salmon DA, Moulton LH, Omer SB, Chace LM, Klassen A, Talebian $\mathrm{P}$ et al. Knowledge, attitudes, and beliefs of school nurses and personnel and associations with nonmedical immunization exemptions. Pediatrics. 2004 Jun;113(6);e552-9

26. Willis N, Hill S, Kaufman J, Lewin S, Kis-Rigo J, De Castro Freire SB et al. "Communicate to vaccinate": the development of a taxonomy of communication interventions to improve routine childhood vaccination. BMC Int Health Hum Rights. 2013 May 11;13:23

27. Jacobson RM, Van Etta L., Bahta L. The c.a.s.e aproach: guidance for talking to vaccine hestant parents. Minn Med. 2013 Apr;96(4);49-50

28. Shelby A, Ernst K. Story and science: how providers and parents can utilize storytelling to combat anti-vaccine misinformation. HumVaccin Immunother. 2013 Aug;9(8):1795-801

29. Opel DJ, Taylor J, Mangione-Smith R, Solomon C, Catz S, Martin D. Validity of a survey to identify vaccine - hesitant parents. Vaccine. 2011;29:6598-6605.

30. Stefanoff P, Mamelund SE, Robinson M, Netterlid E, Tuells J, Bergsaker MA et al. Tracking parental attitudes on vaccination across European countries: The vaccine safety, attitudes, training and communication project (VACSATC). Vaccine. $2010 ; 28 ; 5731-5737$

31.Coniglio, M.A., Platania, M., Privitera, D., Giammanco, G., Pignato, S. Parents' attitudes and behaviours towards recommended vaccinations in Sicily, Italy. BMC Public Health. 201 1;11; 305

32. Rogers, C. Parents' vaccine beliefs: a study of experiences and attitudes among parents of children in private pre-schools. Rhode Island Medical Journal. 2014;6;27-30

33. Link-Gelles R, Chamberlain AT, Schulkin J, Ault K, Whitney E, Seib K et al. Missed opportunities: a national survey of obstetricians about attitudes on maternal and infant immunization. Matern Child Health. 2012;16;1743-1747

34. Tickner S, Leman PJ, Woodcock A. The immunisation beliefs and intentions measure (IBIM): predicting parents' intentions to immunise preschool children. Vaccine. 2010;28;3350-3362

35. Cooper LZ, Larson HJ, Katz SL. Protecting public trust in imuzation. Pediatrics. 2008 Jul;122(1):149-53 
36. Ashbaugh AR, Herbert CF, Saimon E, Azoulay $\mathrm{N}$, Olivera-Figueroa $\mathrm{L}$. The decision to vaccinate or not during the H1N1 pandemic: selecting the lesser of two evils? PLOSONE. 2012;8(3); e58852

37. Willis N1, Hill S, Kaufman J, Lewin S, Kis-Rigo J, De Castro Freire SB et al. "Communicate to vaccinate": the development of a taxonomy of communication interventions to improve routine childhood vaccination.BMC Int Health Hum Rights. 2013 May 11;13:23

38. Salmon DA, Moulton LH, Omer SB, de Hart MP, Stokely S, Halsey NA. Factors associated with refusal of childhood vaccines among parents of school-aged children: a case-control study. Arch Pediatr Adolesc Med. 2005;159:470-6

39. Kennedy AM, Brown CJ, Gust DA. Vaccine beliefs of parents who oppose compulsory vaccination. Public Health Rep. 2005;120:252-8

40. Salmon DA, Moulton LH, Omer SB, Chace LM, Klassen A, Talebian $\mathrm{P}$ et al. Knowledge, attitudes, and beliefs of school nurses and personnel and associations with nonmedical immunization exemptions. Pediatrics. 2004 Jun;113(6);552-9

41. Brunson EK. The impact of social networks on parents' vaccination decisions. Pediatrics 2013;131:1397-404
42. Opel DJ, Mangione-Smith R, Robinson JD, Heritage J, DeVere V, Salas HS et al. The influence of provider communication behaviors on parental vaccine acceptance and visit experience. Am J Public Health 2015;105: 1998-2004

43. Fairbrother G, Fuentes-Afflick E, Ross LF, Thomas PA. Communicating with parents about immunization safety: messages for pediatricians in the IOM report "the childhood immunization schedule and safety: stakeholder concerns, scientific evidence, and future studies". Acad Pediatr 2013;13:387-9

44. Forkner-Dunn J. J. Internet-based patient self-care: the next generation of health care delivery. Med Internet Res. 2003;5:0

45. Keelan J, Pavri-Garcia V, Tomlinson G, Wilson $\mathrm{K}$. YouTube as a source of information on immunization: a content analysis. JAMA. 2007;298:2482-2484

46. Seeman N, Ing A, Rizo C. Healthc Q. Assessing and responding in real time to online anti-vaccine sentiment during a flu pandemic. 2010;13:815

47. Kata A. Anti-vaccine activists, web 2.0, and the postmodern paradigm--an overview of tactics and tropes used online by the anti-vaccination movement. Vaccine. 2012;30:3778-378 


\title{
THE IMPORTANCE OF COMMUNICATION IN PREVENTION OF ANTI-VACCINATION ACTIVITIES
}

\author{
Darjan Franjić1 Ivana Franjić $^{2}$, Jelena Ravlija ${ }^{3}$ \\ ${ }^{1}$ Department of Oncology, University Clinical Hospital Mostar, 88000 Mostar, B\&H \\ ${ }^{2}$ Unit of Intensive Care, University Clinical Hospital Mostar, 88000 Mostar, B\&H \\ ${ }^{3}$ Faculty of Health Studies, University of Mostar, 88000 Mostar, B\&H
}

\begin{abstract}
INTRODUCTION: Vaccination of children is an effective way to prevent serious childhood diseases, however many children do not receive the recommended vaccines. Communication about childhood vaccination with parents is one of the most important ways to address vaccination issues.

OBJECTIVE: The objective of this study is to examine the importance of communication in prevention of anti-vaccination activities and determine the information sources on vaccination most commonly used by parents. An additional objective is to evaluate the shortcomings in communication between physician/nurse and parents as one of possible reasons for the rejection of vaccination of children by parents.

METHODS: We used theParent Attitudes about Childhood Vaccines (PACV) Survey Tool on a regular systematic sample of 60 parents. The survey was linguistically validated and approved by the author. The subjects were parents of children up to the age of 14 who were present at the Children's Clinic of the Community Health Care Centre Mostar.

RESULTS: For $67 \%$ of the respondents the reason for vaccination of their children is protection from diseases, $13 \%$ of them think that a child should be vaccinated because vaccination is required by law and $23 \%$ of them hold an opinion that diseases have a higher risk for complications than vaccinations. $83 \%$ of the respondents have regularly vaccinated their children according to their age while $17 \%$ did not. $67 \%$ of them claim that the physician or nurse fully explain the procedure of vaccination, $31 \%$ of them claim that the procedure is only partly explained, while $2 \%$ of the respondents claim that the procedure is not explained at all.
\end{abstract}

CONCLUSION: The most common source of information for parents are healthcare workers but also the internet and friends. The healthcare staff should be a source of reliable information about the benefits and possible side effects of vaccination.

Key words: vaccination, communication, prevention, information, anti-vaccination movement

Correspondence:

Darjan Franjić, MA

e-mail: darjanfranjic@gmail.com 